\section{Parameters of glycemic control in type 2 diabetic patients on hemodialysis or peritoneal dialysis: implications for clinical practice}

\author{
Parâmetros do controle glicêmico em pacientes com \\ diabetes melito tipo 2 em hemodiálise ou diálise \\ peritoneal: implicações para a prática clínica
}

Maria Valeria Pavan', Cibele Isaac Saad Rodrigues², Ronaldo D'Ávila², Enio Marcio Maia Guerra ${ }^{2}$, Ricardo Augusto de Miranda Cadaval ${ }^{2}$,

Fernando Antonio de Almeida ${ }^{2}$

\begin{abstract}
Objective: To better explore the relationship between parameters of glycemic control of T2DM in RRT, we studied 23 patients on hemodialysis (HD), 22 on peritoneal dialysis (PD), and compared them with 24T2DM patients with normal renal function (NRF). Materials and methods: We performed, on four consecutive days, 10 assessments of capillary blood glucose [4 fasting, 2 pre- and 4 postprandial (post-G) and average (AG)], random glycemia, and HbA1c in all patients. Results: Preprandial blood glucose was greater in patients on RRT compared with NRF. Correlations between $A G$ and $\mathrm{HbA} 1 \mathrm{c}$ were 0.76 for $\mathrm{HD}, 0.66$ for PD, and 0.82 for NRF. The regression lines between $A G$ and $\mathrm{HbA} 1 \mathrm{c}$ were similar for patients on $\mathrm{HD}$ and with NFR, but they were displaced upward for PD. Conclusion: Similar HbA1c values in PD patients may correspond to greater levels of AG than in HD or NRF patients. Arq Bras Endocrinol Metab. 2013;57(6):457-63
\end{abstract}

\section{Keywords}

Type 2 diabetes mellitus; hemodialysis; peritoneal dialysis; hemoglobin A1c; end-stage renal disease

\section{RESUMO}

Objetivo: Para melhor explorar a relação entre os parâmetros de controle glicêmico em DM2 em TRS, estudamos 23 pacientes em hemodiálise (HD), 22 em diálise peritoneal (DP) em comparação à $24 \mathrm{DM} 2$ com função renal normal (FRN). Materiais e métodos: Em quatro dias consecutivos, realizamos 10 glicemias capilares [4 em jejum, 2 pré- e 4 pós-prandiais (G-pós) e a média glicêmica (MG)], glicemia aleatória e HbA1c em todos os pacientes. Resultados: As glicemias pré-prandiais foram mais elevadas nos pacientes em TRS se comparadas àqueles com FRN. As correlações entre $M G$ e HbA1c foram em $\mathrm{HD}=0,76 ; \mathrm{DP}=0,66$ e $\mathrm{FRN}=0,82$. As retas de regressão entre MG e HbA1c assemelham-se nos pacientes em HD e NFR e estão deslocadas para cima em DP. Conclusão: Valores similares de HbA1c podem corresponder a MG maiores em pacientes em DP do que em HD ou FRN. Arq Bras Endocrinol Metab. 2013;57(6):457-63

Descritores

Diabetes melito tipo 2; hemodiálise; diálise peritoneal; hemoglobina A glicosilada; doença renal terminal
${ }^{1}$ Centro de Diálise e Transplante Renal, Hospital Santa Lucinda, Pontifícia Universidade Católica de São Paulo (PUCSP), Sorocaba, SP, Brazil ${ }^{2}$ Nephrology Division at Faculdade de Ciências Médicas e de Saúde, PUC-SP, Sorocaba, SP, Brazil
Correspondence to: Fernando Antonio de Almeida Departamento de Medicina Rua Joubert Wey, 290 18030-230 - Sorocaba, SP, Brazil faalmeida@globo.com faalmeida@pucsp.br

Received on Apr/18/2012 Accepted on Apr/10/2013 


\section{INTRODUCTION}

$\mathrm{D}$ iabetic nephropathy is the leading cause of end-stage renal disease (ESRD) in many countries (1-4). Furthermore, the mortality of diabetic patients on renal replacement therapy (RRT), independent on the dialysis method, is greater than in comparable patients without diabetes $(4,5)$. Many factors may be associated with the increased mortality rate of diabetic patients under dialysis, such as older age, gender, hypoalbuminemia, malnutrition and inflammation, smoking, dialysis vintage, dialysis dose, arrhythmia or left ventricular hypertrophy, prior cardiovascular events, hypocholesterolemia, hyperphosphatemia, and poor glycemic control before or during dialysis (412). However, there is lack of information about the effects of improving glycemic control on morbidity and mortality in patients with diabetes on hemodialysis and peritoneal dialysis (PD). Moreover, the goals for glycemic control parameters used in patients with diabetes on RRT have been the same as those used in patients with preserved renal function, particularly, blood or capillary glucose and glycated hemoglobin $(\mathrm{HbAlc})$. Indeed, we do not even know if values indicating good glycemic control for individuals without renal failure also apply for those under dialysis, particularly on PD. One previous study has shown that diabetic patients on hemodialysis had greater values of HbAlc for the same average glucose levels than patients with preserved renal function in the DCCT trial (13). In the last decade, there has been increasing evidence of an association between $\mathrm{HbAlc}$ levels and long-term morbidity and mortality rates in diabetic patients on dialysis. In a Japanese diabetic population receiving hemodialysis, predialysis HbAlc levels greater than $8 \%$ were associated with greater mortality rates over a 7-year follow-up (14). In a large setting of US diabetic patients under hemodialysis, the non-anemic patients (hemoglobin $>11 \mathrm{~g} / \mathrm{dL}$ ) had increasing mortality risk for $\mathrm{HbAlc}$ levels greater than $6 \%$, even after adjustment for many confounders (15). In a German multicentric study, the T2DM patients on hemodialysis with greater levels of $\mathrm{HbAlc}$ at baseline had greater risk of cardiovascular and all-cause mortality in a 4-year follow-up period (16).

Recently, the ADAG Study established the correspondence of $\mathrm{HbAlc}$ with average serum glucose level in a large population of normal individuals and patients with type 1 or type 2 diabetes (17). These data became reference for the correspondence of $\mathrm{HbAlc}$ and aver- age glucose levels and are recommended for use in clinical practice, but that study excluded diabetic patients with chronic renal disease (CRD) (17).

Taking these findings into account, the aim of the present study was to investigate the most useful parameters of glycemic control in patients with type 2 diabetes under RRT (hemodialysis or PD) and compare them with those in diabetic individuals with normal renal function. For this study, we used the average of blood glucose values (AG: mean 10 values of fasting, preprandial and postprandial capillary glycemia) as the reference for glycemic control, and correlated it with HbAlc or compared it with postprandial glycemia and to random glycemia. Random glycemia is usually taken as a parameter of glycemic control in the majority of patients receiving dialysis.

\section{MATERIALS AND METHODS}

\section{Patients}

We identified diabetic patients with normal renal function and diabetic patients receiving hemodialysis or PD at Centro de Diálise e Transplante Renal - Hospital Santa Lucinda, Pontifícia Universidade Católica de São Paulo, Sorocaba, SP, Brazil. The inclusion criteria were age over 18 years; diagnosis of type 2 diabetes mellitus; and when on RRT, patients must have been on hemodialysis three times weekly or PD for at least three months, and must have had stable hemoglobin level and erythropoietin dose. The exclusion criteria were blood transfusion in the previous three months; diagnosis of an immune or hereditary hemolytic anemia, and inability or unwillingness to perform the required protocol measurements.

For hemodialysis adequacy, patients were dialyzed without glucose in the dialysis bath in accordance with The National Kidney Foundation guidelines (US) also called The Kidney Disease Outcome Quality Improvement Initiative (18). Patients on PD performed four 2 -liter exchanges per day. Usually, the first exchange in the morning was of hypertonic dialysis solution $(4.25 \%$ glucose), and the remaining exchanges were isotonic ( $1.5 \%$ glucose). A total of 45 patients with type 2 diabetes receiving hemodialysis $(\mathrm{n}=23)$ or $\mathrm{PD}(\mathrm{n}=22)$, and 24 type 2 diabetic patients with normal renal function, who were selected as controls, participated in the study.

During the study procedures, patients were recommended to maintain their usual food intake and 
not change their regular doses of oral hypoglycemiants or insulin. Patients with normal renal function usually took sulphonilurea alone or sulphonilurea plus metformin and/or NPH insulin, whereas patients on dialysis were under NPH insulin therapy or only on diet $(n=3)$. Two out of 20 patients on hemodialysis received lower doses of NPH insulin on the day of hemodialysis (6 units less than on hemodialysis days). The mean daily dose of NPH insulin in hemodialysis patients was 23 units (range: 8 to 56 units), and in PD patients, 42 units (range: 12 to 72 units). After all the study procedures were explained, the participants read and signed an informed consent form, were clinically evaluated, and laboratorial parameters were recorded.

\section{Parameters of glycemic control}

To determine capillary glycemia, patients were provided and instructed on how to use the Accu-Chek Advantage capillary glucose meter (Roche Diagnostic GmbH, Mannheim, Germany) to obtain a total of 10 measurements during four consecutive days ( 2 days on and 2 days off hemodialysis). Capillary glucose measurements were done twice daily (fasting and preprandial), or three times daily (one fasting and 2 postprandial). The patients or one relative was trained to correctly manage the capillary glucose meter. The instructions were repeated several times by the study personnel. The patients had to prove their ability to perform these tests before actually participating in the study. Capillary glucose measurements consisted of 10 predefined time points: four fasting, two preprandial, and four two-hour postprandial assessments. A data collection form was provided to each patient to record the test results. Glucose measurements were stored in the glucose meter's memory so that confirmation of the patient-reported data could be assessed for accuracy. When the results of the written test and those recorded in the glucose meter memory differed, values stored in the meter memory were considered correct. On the final day of capillary glucose determination, blood was collected to assess random plasma glucose, $\mathrm{HbAlc}$, creatinine, urea, albumin, hematocrit, and hemoglobin.

The study protocol was approved by the institutional review board of the Faculdade de Ciências Médicas e da Saúde - Pontifícia Universidade Católica de São Paulo, and was conducted according to the International Good Clinical Practice Harmonization and the Declaration of Helsinki.

\section{Assays}

HbAlc was assessed by immunoassay (Roche Diagnostic GmbH - TQ HbAlc, Mannheim, Germany), as certified by the National Glycohemoglobin Standardization Program (NGSP, USA), which has a normal range of $4 \%$ to $6 \%$. Plasma glucose and other biochemical parameters were determined using an automated chemistry analyzer (LabMax 240, Labtest Diagnostica, 33400-000 Belo Horizonte, Brazil). Hematology analysis was performed using the ABX Pentra ES 60 (Horiba ABX Ltda, 04795-100 São Paulo, Brazil).

\section{Statistical analysis}

For statistical analysis, IBM ${ }^{\circledast}$ SPSS $^{\circledast}$ Statistics Professional (Somers, NY, USA) was used. All data are expressed as mean \pm standard deviation. For comparisons between means and variance of different groups, ANOVA followed by Tukey's test was used. For correlation between different parameters Pearson's correlation coefficient followed by regression analysis was used.

\section{RESULTS}

Demographic data and clinical characteristics of the diabetic patients with normal renal function, on hemodialysis, and on PD are presented in table 1. Patient age was similar among groups. Time from diagnosis of T2DM was longer in patients receiving hemodialysis or PD than diabetic patients with normal renal function. No differences were observed between PD and hemodialysis patients in the time from T2DM diagnosis, time on RRT, plasma creatinine, hematocrit level, or hemoglobin level. Serum albumin and pre-dialysis urea levels were greater in patients receiving hemodialysis compared with those on PD. All patients receiving dialysis and $66 \%$ of diabetic patients with normal renal function had hypertension.

Table 2 shows the glycemic and HbAlc values of all groups. Fasting glycemic values showed no differences among groups. In contrast, preprandial capillary glucose was greater in hemodialysis and PD patients compared with diabetic patients with normal renal function. Most patients on PD uses hypertonic (4.25\% glucose) dialysis solution as the first exchange in the morning. Postprandial glucose, AG, and random glycemia did not differ among groups. Diabetic patients on hemodialysis had greater $\mathrm{HbAlc}$ compared with diabetic patients on PD and those with normal renal function. 
Table 1. Clinical characteristics of patients with type 2 diabetes

\begin{tabular}{|c|c|c|c|}
\hline & $\begin{array}{l}\text { Normal renal } \\
\text { function } \\
(\mathbf{n}=24)\end{array}$ & $\begin{array}{l}\text { Hemodialysis } \\
\quad(n=23)\end{array}$ & $\begin{array}{l}\text { Peritoneal } \\
\text { dialysis } \\
(n=22)\end{array}$ \\
\hline Age (years) & $51.3 \pm 16.1$ & $57.2 \pm 10.4^{*}$ & $56.5 \pm 12.9^{*}$ \\
\hline Gender & $11 \mathrm{~F} / 13 \mathrm{M}$ & $8 \mathrm{~F} / 15 \mathrm{M}$ & $10 \mathrm{~F} / 12 \mathrm{M}$ \\
\hline $\begin{array}{l}\text { Time from } \\
\text { diagnosis of } \\
\text { T2DM+ (years) }^{+} \mathrm{DM}^{+} \text {(year }\end{array}$ & $6.2 \pm 6.7$ & $17.0 \pm 4.5^{\star}$ & $14.0 \pm 8.7^{\star}$ \\
\hline $\begin{array}{l}\text { Time on RRT } \\
\text { (months) }\end{array}$ & & $22.9 \pm 21.6$ & $18.4 \pm 11.0$ \\
\hline $\begin{array}{l}\text { Serum } \\
\text { creatinine }^{\S} \\
(\mathrm{mg} / \mathrm{dL})\end{array}$ & $0.9 \pm 0.2$ & $9.0 \pm 3.5^{\star}$ & $7.3 \pm 2.1^{\star}$ \\
\hline $\begin{array}{l}\text { Serum urea } \\
\text { nitrogen§ } \\
(\mathrm{mg} / \mathrm{dL})\end{array}$ & $13.1 \pm 1.9$ & $75.2 \pm 16.8^{*}$ & $50.9 \pm 17.3^{* \|}$ \\
\hline $\begin{array}{l}\text { Hematocrit } \\
(\%)\end{array}$ & $43.2 \pm 4.3$ & $34.5 \pm 8.5^{*}$ & $33.3 \pm 3.6^{\star}$ \\
\hline $\begin{array}{l}\text { Hemoglobin } \\
(\mathrm{g} / \mathrm{dL})\end{array}$ & $14.1 \pm 1.4$ & $11.2 \pm 2.8^{*}$ & $11.0 \pm 1.2^{*}$ \\
\hline $\begin{array}{l}\text { Albumin } \\
(\mathrm{g} / \mathrm{dL})\end{array}$ & $3.9 \pm 0.4$ & $3.7 \pm 0.5$ & $3.3 \pm 0.4^{* \|}$ \\
\hline $\begin{array}{l}\text { Hypertension - } \\
\text { number (\%) }\end{array}$ & 17 (70\%) & $23(100 \%)^{*}$ & $22(100 \%)^{\star}$ \\
\hline
\end{tabular}

Values are mean $\pm \mathrm{SD} ;{ }^{*}=\mathrm{p}<0.01$ versus normal renal function; ${ }^{\dagger}=$ type 2 diabetes mellitus; ${ }^{\ddagger}=$ renal replacement therapy; ${ }^{\S}=$ random values of serum creatinine and serum urea nitrogen for normal renal function and peritoneal dialysis patients, and values pre-hemodialysis for the hemodialysis patients; " $=p<0.01$ hemodialysis versus peritoneal dialysis. Conversion factors for units: serum creatinine in $\mathrm{mg} / \mathrm{dL}$ to $\mu \mathrm{mol} / \mathrm{L}$, $\mathrm{x} 88.4$; serum urea nitrogen in $\mathrm{mg} / \mathrm{dL}$ to $\mathrm{mmol} / \mathrm{L}$, $\mathrm{x} 0.357$; hemoglobin in $\mathrm{g} / \mathrm{dL}$ to $\mathrm{g} / \mathrm{L}, \mathrm{x} 10$; albumin in $\mathrm{g} / \mathrm{dL}$ to $\mathrm{g} / \mathrm{L}, \mathrm{x} 10$.

Table 2. Blood glucose in patients with type 2 diabetes

\begin{tabular}{lccc}
\hline & $\begin{array}{c}\text { Normal renal } \\
\text { function } \\
\text { (n= 24) }\end{array}$ & $\begin{array}{c}\text { Hemodialysis } \\
(\mathbf{n = 2 3 )}\end{array}$ & $\begin{array}{c}\text { Peritoneal } \\
\text { dialysis } \\
(\mathbf{n = 2 2})\end{array}$ \\
\hline $\begin{array}{l}\text { Fasting } \\
\text { glycemia* } \\
\text { (mg/dL) }\end{array}$ & $163 \pm 54$ & $157 \pm 55$ & $165 \pm 58$ \\
$\begin{array}{l}\text { Preprandial } \\
\text { glycemia }\end{array}$ & $178 \pm 87$ & $213 \pm 111^{\dagger}$ & $218 \pm 110^{\ddagger \S}$ \\
(mg/dL) & & & \\
$\begin{array}{l}\text { Postprandial } \\
\text { glycemia (mg/dL) }\end{array}$ & $194 \pm 75^{\ddagger}$ & $235 \pm 87^{\ddagger}$ & $211 \pm 86^{\ddagger}$ \\
$\begin{array}{l}\text { Average of blood } \\
\text { glucose values" } \\
\text { (mg/dL) }\end{array}$ & $179 \pm 61$ & $195 \pm 71$ & $202 \pm 74$ \\
$\begin{array}{l}\text { Random } \\
\text { glycemia } \\
\text { (mg/dL) }\end{array}$ & $172 \pm 79$ & $208 \pm 115$ & $177 \pm 91$ \\
HbA1c (\%) & $7,6 \pm 2.0$ & $8.5 \pm 1.6^{\sharp}$ & $7.1 \pm 1.4$ \\
\hline
\end{tabular}

Values are mean $\pm \mathrm{SD}$; ${ }^{*}=$ fasting glycemia determined before any meal and before the first peritoneal dialysis exchange of the day; ${ }^{\dagger}=$ most patients in peritoneal dialysis used a hypertonic ( $4.25 \%$ glucose) dialysis solution as the first exchange in the morning; ${ }^{\ddagger}=p<0.01$ versus fasting glycemia; ${ }^{\S}=p<0.01$ versus normal renal function; " = mean of 10 values determined on 4 consecutive days; $"$ = for random glycemia, blood was collected any time of the day; ${ }^{\#}=p<0.01$ hemodialysis versus peritoneal dialysis. Conversion factors for units: glycemia in $\mathrm{mg} / \mathrm{dL}$ to $\mathrm{mmol} / \mathrm{L}, \times 0.05551$.
Table 3 depicts Pearson's correlation coefficients between different parameters of glycemic control. All parameters were significantly correlated with each other $(\mathrm{p}<0.01)$. As expected, HbAlc was correlated with $A G$ in patients with normal renal function $(r=0.82)$ and hemodialysis patients $(\mathrm{r}=0.76)$, but Person's correlation index for PD patients was only fair $(r=0.66)$.

Figure 1 shows the scatter plot of the individual data and the linear regression for the correlation of $A G$ with HbAlc. In figure 1, graph A represents data from diabetic patients with normal renal function, graph $\mathrm{B}$ expresses data from hemodialysis patients and graph $\mathrm{C}$ shows the values from patients on PD. There was a good correlation between $A G$ and $\mathrm{HbAlc}$ for patients with normal renal function and those on hemodialysis, but this correlation was lower in patients on PD due to the great variation of individual data.

Figure 2 compares the regression lines that represent the correspondence of $\mathrm{AG}$ and $\mathrm{HbAlc}$ for the three groups of patients. As a reference, the regression line published in the ADAG Study, the most recommended in recent clinical practice, is included (17). The regression line for patients with normal renal function was very close to that of the ADAG Study. On the other hand, the regression line was steeper for hemodialysis and PD patients, and that for PD was displaced upward. If we considered the most prevalent range of HbAlc values, that is, from $6 \%$ to $10 \%$, the correspondence between AG and $\mathrm{HbAlc}$ was similar in patients with normal renal function compared with those on he-

Table 3. Pearson's correlation coefficients between different glycemic control parameters

\begin{tabular}{lccc}
\hline & $\begin{array}{c}\text { Normal renal } \\
\text { function } \\
(\mathbf{n = 2 4 )}\end{array}$ & $\begin{array}{c}\text { Hemodialysis } \\
(\mathbf{n = 2 3 )}\end{array}$ & $\begin{array}{c}\text { Peritoneal } \\
\text { dialysis } \\
(\mathbf{n = 2 2})\end{array}$ \\
\hline $\begin{array}{l}\text { Fasting glycemia } \\
\text { versus random } \\
\text { glycemia }\end{array}$ & 0.65 & 0.66 & 0.77 \\
$\begin{array}{l}\text { Fasting glycemia } \\
\text { versus HbA1c }\end{array}$ & 0.72 & 0.82 & 0.57 \\
$\begin{array}{l}\text { Preprandial } \\
\text { glycemia versus }\end{array}$ & 0.72 & 0.72 & 0.71 \\
$\begin{array}{l}\text { HbA1c } \\
\text { Postprandial } \\
\text { glycemia versus }\end{array}$ & 0.73 & 0.67 & \\
HbA1c & & & 0.58 \\
$\begin{array}{l}\text { Average of blood } \\
\text { glucose values } \\
\text { versus HbA1c }\end{array}$ & 0.82 & 0.76 & \\
\hline
\end{tabular}

All indexes were significant $(p<0.01)$. 
modialysis, whereas patients on PD would have greater $\mathrm{AG}$ for a given value of HbAlc. For instance, the same value of $A G$ of $200 \mathrm{mg} / \mathrm{dL}$ would result in different HbAlc level in patients on PD (nearly 7.5\%) compared with those on hemodialysis or with normal renal function (about $8.5 \%$ ). In other words, the same level of HbAlc (such as $9 \%$ ) would correspond to a $30-\mathrm{mg} / \mathrm{dL}$ greater value of AG in patients on PD.
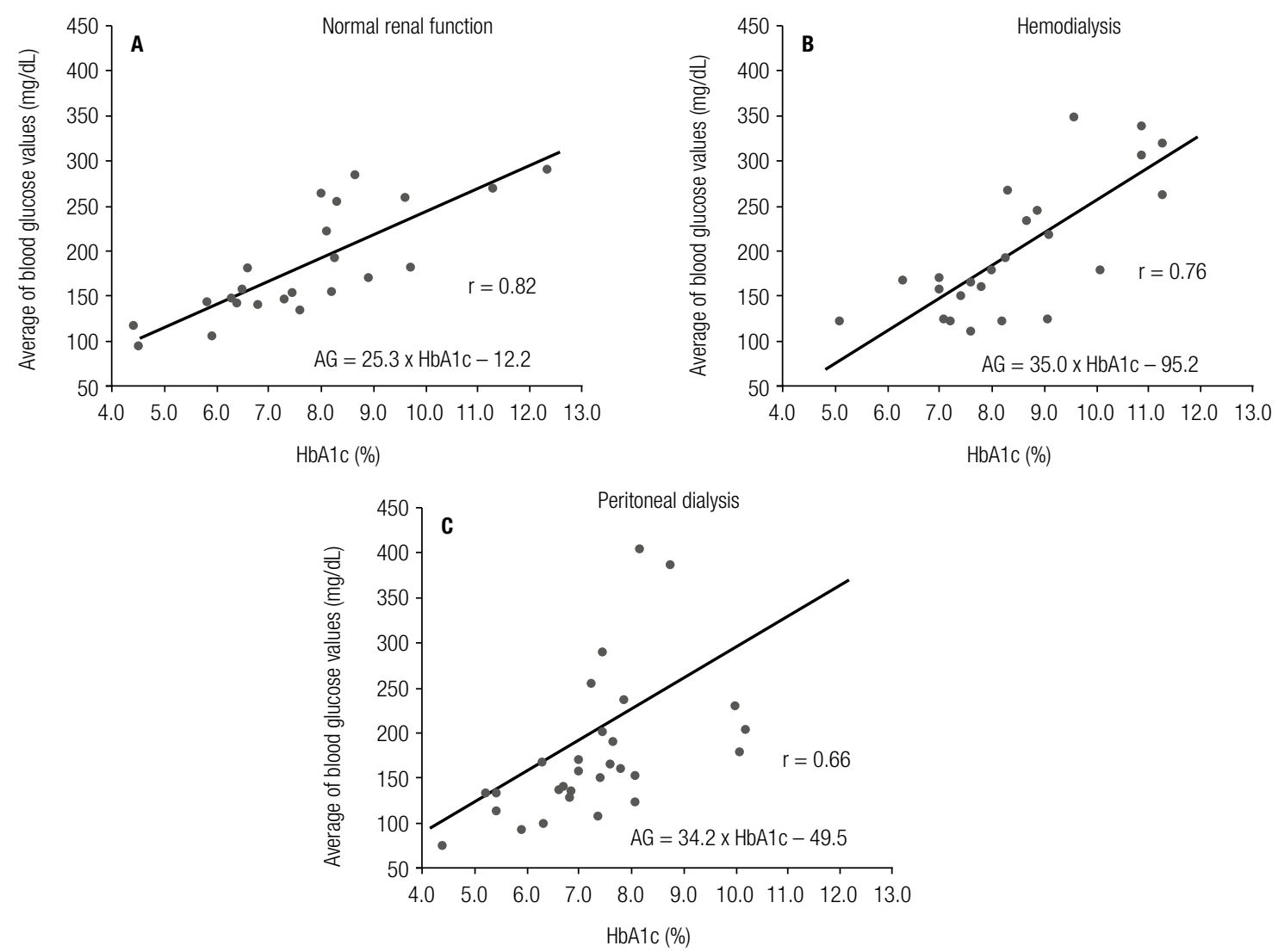

Figure 1. Correlation between average of blood glucose values and postprandial glycemia or $\mathrm{HbA1C}$.

Graph A represents type 2 diabetic patients with normal renal function, Graph B represents type 2 diabetic patients on hemodialysis, and Graph C represents type 2 diabetes patients on peritoneal dialysis. $A G=$ average of blood glucose values, $\mathrm{HbA1C}=$ hemoglobin A1c. Pearson's correlation indexes (r) are shown inside the graphs, as well as the equation for best-fitting regression lines.

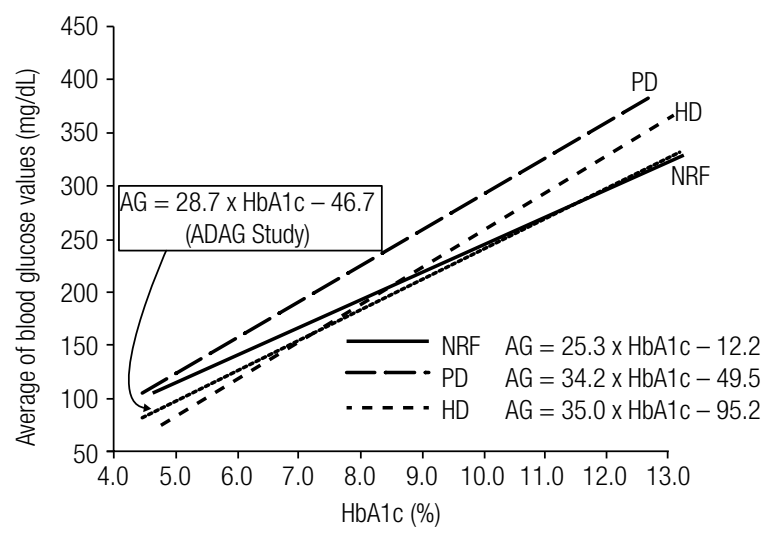

Figure 2. Regression lines for type 2 diabetic patients with normal renal function, on hemodialysis, and on peritoneal dialysis.

Best-fitting regression lines for type 2 diabetic patients with normal renal function (NRF), on hemodialysis (HD) and on peritoneal dialysis (PD), as well as the regression line from the ADAG study (17). Inside the graph are the equations for the best-fitting regression lines. 


\section{DISCUSSION}

In this study, we observed that, despite similar values of fasting glycemia and AG in the three groups of diabetic patients, those on RRT had greater preprandial glycemic levels. This finding may have resulted from the insulin resistance and glucose metabolism alterations characteristic of ESRD (19). Second, patients on hemodialysis had greater HbAlc compared with diabetics with normal renal function or those on PD (Table 2 ). This finding is in accordance with previous data in a similar group of diabetic patients on hemodialysis (13). Third, HbAlc correlated well with AG in all groups (Table 3 and Figure 1), but the regression line of AG versus $\mathrm{HbAlc}$ in patients on $\mathrm{PD}$ was clearly displaced upward, meaning greater $A G$ values for a given level of HbAlc (Figure 2). Although the slopes of the regression lines of AG versus $\mathrm{HbAlc}$ for hemodialysis and PD patients were slightly steeper than in the normal renal function patients and in the ADAG study (17), our data allow us to translate $\mathrm{HbAlc}$ into average glucose values (and vice versa) using the equations that represent the best-fit regression line (Figures 1 and 2 ).

We believe that there were no important variations on blood glucose levels during the study days and the period that HbAlc represents, because we recommended to the participants not to change their usual food intake and medication. Furthermore, if there were any variation during the day on dialysis compared with days off, they could not be accounted for changes in capillary glucose, for AG or for $\mathrm{HbAlc}$, because data collection was carried out during two hemodialysis days and two non-dialysis days, similarly to what happens on a regular dialysis period.

It is important to evaluate how these findings may impact the management of glycemic control and prognosis of type 2 diabetic patients on dialysis. In diabetic patients with preserved renal function, postprandial glucose is an independent risk factor and correlates better with morbidity and mortality than fasting glucose $(20,21)$. However, we have no information on the relevance of postprandial glucose in the prognosis of diabetic patients under dialysis. Although data on PD are scarce, HbAlc is a good marker of prognosis in patients receiving hemodialysis (11-12,14-16). Thus, besides HbAlc, postprandial glucose should be better explored in future studies of patients on dialysis, particularly in those on PD.

Considering the differences among the groups in the relationship between AG and HbAlc obtained in our study, one should be cautious when comparing values of HbAlc of diabetic patients on hemodialysis, on PD or with preserved renal function. Furthermore, we also must consider that for our patients on $\mathrm{PD}$, values of AG versus $\mathrm{HbAlc}$ had the greatest dispersion and the lowest correlation index $(\mathrm{r}=0.66)$ among the three groups of patients. Thus, this must be considered an important limitation of this study, as well as the number of patients in each group.

Finally, these new data must be confirmed in other settings of diabetic patients receiving dialysis. Also, further studies are required to explore whether HbAlc is a valuable marker of morbidity and mortality, and whether it may serve to advise interventions to improve glycemic control and, thus, the prognosis of diabetic patients undergoing RRT.

Acknowledgements: Accu-Chek Advantage capillary glucose meters were kindly provided by Roche Diagnostica, São Paulo, SP, Brazil.

Disclosure: no potential conflict of interest relevant to this article was reported.

\section{REFERENCES}

1. Atkins RC. The epidemiology of chronic kidney disease. Kidney Int. 2005;67(suppl 94):S14-8.

2. Stewart JH, McCredie MR, Williams SM, Jager KJ, Trpeski L, McDonald SP; ESRD Incidence Study Group. Trends in incidence of treated end-stage renal disease, overall and by primary renal disease, in persons aged 20-64 years in Europe, Canada and the Asia-Pacific region, 1998-2002. Nephrology (Carlton). 2007; 12:520-7.

3. Boddana P, Caskey F, Casula A, Ansell D. UK Renal Registry 11th Annual Report (December 2008): Chapter 14 UK Renal Registry and international comparisons. Nephron Clin Pract. 2009;111(suppl 1):c269-76.

4. US Renal Data System - USRDS 2010 Annual Data Report. Bethesda, MA: National Institute of Health, National Institute of Diabetes and Digestive and Kidney Diseases; 2010.

5. Goldwasser P, Mittman N, Antignani A, Burrell D, Michel MA, Collier $\mathrm{J}$, et al. Predictors of mortality in hemodialysis patients. $J$ Am Soc Nephrol. 1993;3:1613-22.

6. Chertow GM, Johansen KL, Lew N, Lazarus JM, Lowrie EG. Vintage, nutritional status, and survival in hemodialysis patients. Kidney Int 2000;57:1176-81.

7. Cheung AK, Sarnak MJ, Yan G, Heyka RJ, Rocco MV, Teehan BP, et al. Atherosclerotic cardiovascular disease risks in chronic hemodialysis patients. Kidney Int. 2000;58:353-62.

8. Locatelli F, Pietro Pozzoni P, Del Vecchio L. Renal replacement therapy in patients with diabetes and end-stage renal disease. J Am Soc Nephrol. 2004;15(suppl 1):S25-9.

9. Shik J, Parfrey PS. The clinical epidemiology of cardiovascular disease in chronic kidney disease. Curr Opin Nephrol Hypertens. 2005; 14:550-7.

10. Krane V, Heinrich F, Meesmann M, Olschewski M, Lilienthal J, Angermann C, et al, German Diabetes and Dialysis Study Investiga- 
tors. Electrocardiography and outcome in patients with diabetes mellitus on maintenance hemodialysis. Clin J Am Soc Nephrol. 2009;4:394-400.

11. Chung SH, Han DC, Noh H, Jeon JS, Kwon SH, Lindholm B, et al. Risk factors for mortality in diabetic peritoneal dialysis patients. Nephrol Dial Transplant. 2010;25:3742-8.

12. Carrero JJ, Mutsert R, Axelsson J, Dekkers OM, Jager KJ, Boeschoten EW, et al.; for the NECOSAD Study Group. Sex differences in the impact of diabetes on mortality in chronic dialysis patients. Nephrol DialTransplant. 2011;26:270-6.

13. Joy MS, Cefalu WT, Hogan SL, Nachman PH. Long-term glycemic control measurements in diabetic patients receiving hemodialysis. Am J Kidney Dis. 2002;39:297-307.

14. Oomichi T, Emoto M, Tabata T, Morioka T, Tsujimoto Y, Tahara H, et al. Impact of glycemic control on survival of diabetic patients on chronic regular hemodialysis: a 7-year observational study. Diabetes Care. 2006;29:1496-500.

15. Kalantar-Zadeh K, Kopple JD, Regidor DL, Jing J, Shinaberger CS, Aronovitz $\mathrm{J}$, et al. A1C and survival in maintenance hemodialysis patients. Diabetes Care. 2007;30:1049-55.
16. Drechsler C, Krane V, Ritz E, März W, Wanner C. Glycemic control and cardiovascular events in diabetic hemodialysis patients. Circulation. 2009;120:2421-8.

17. Nathan DM, Kuenen J, Borg R, Zheng H, Schoenfeld D, Heine RJ. A1c-Derived Average Glucose Study Group: Translating the A1C assay into estimated average glucose values. Diabetes Care. 2008;31:1473-8. Erratum in: Diabetes Care 2009;32:207.

18. K/DOQI Clinical Practice Guidelines for Chronic Kidney Disease: evaluation, classification, and stratification evaluation of laboratory measurements for clinical assessment of kidney disease. Am J Kidney Dis. 2002;39(suppl):S1-266.

19. DeFronzo RA, Alvestrand A, Smith D, Hendler R, Hendler E, Wahren J. Insulin resistance in uremia. J Clin Invest. 1981;67:563-8.

20. DECODE Study Group, the European Diabetes Epidemiology Group. Glucose tolerance and cardiovascular mortality: comparison of fasting and 2-hour diagnostic criteria. Arch Intern Med. 2001;161:397-405.

21. Meigs JB, Nathan DM, D'Agostino RB Sr, Wilson PWF. Fasting and postchallenge glycemia and cardiovascular disease risk: the Framingham Offspring Study. Diabetes Care. 2002;25:1845-50. 